\title{
Analysis of The Maize Systems to Increase Production with a Dynamic System Approach
}

\author{
Agung Brastama Putra ${ }^{1}$, Siti Mukaromah ${ }^{2}$, Prisa Marga Kusumantara ${ }^{3}$ \\ Departement of Information System \\ Universitas Pembangunan Nasional "Veteran" Jawa Timur \\ Surabaya, Indonesia \\ 1agungbp.si@ upnjatim.ac.id, ${ }^{2}$ sitimukaromah.si@upnjatim.ac.id, ${ }^{3}$ prisamarga.si@ upnjatim.ac.id
}

\begin{abstract}
Maize is one of the items in agriculture subsector food crops, which has a high-level carbohydrate and substitutes for other food sources besides rice. Maize has its superiority that all of its product's yield can be utilized, starting from seeds, leaves, skin and even maize cobs can be used. East Java Province and Madura island are several provinces of the corn producing areas. Increasing the maize production is accompanied by the mounting consumption in population and industry. Hence, the Government publishes a policy for improvement of production by improving irrigation. This paper will conduct an analysis related to government policy on irrigation improvements to increase maize production by simulating with a system dynamics approach. Besides that, this paper will insert a variable expansion plant area (extensification), improved irrigation performance (intensification) and treatment of maize seed (intensification) to use in scenario model system dynamics. System dynamics approach is used because can give of the information related to variables and feedback to the system.
\end{abstract}

Keywords-maize production analysis; the maize production; System Dynamics Approach; Scenario maize production

\section{INTRODUCTION}

The Minister of Agriculture has published a decree about improvement irrigation to increase maize production [1]. The delay in policy in agricultural systems can make agricultural production declined [2], increases and decreases in production can be caused by the environment, weeds, pests, diseases and rainfall (climate) [3]. The analysis in this field, cultivation system can explain the trend in productivity [4] or connect with alteration environmental or climate variability[5][6].

The maize production every year increase but the maize consumption also increases, while to protect the maize commodity, the government policy to increase production by improving irrigation [1]. The Government policies in East Java and Lampung are not optimal in shading farming and maize commodities in both regions [9]. Averages Productivity of maize is 43.1 quintals/hectare, the highest productivity of 50.52 quintals/hectare in 2015, and the lowes productivity in 2000 (see table I). At present, the maize demand for food in Indonesia attains 7.8 million to 8.5 million tons per year [17]. Treatment seed can improve maize productivity, and enhance the performance of productivity to influence production [18].
TABLE I. The MaIZE Productivity

\begin{tabular}{|c|c|}
\hline Year & $\begin{array}{c}\text { Maize Productivity in East Java } \\
\text { (Quintal/ha) }\end{array}$ \\
\hline 2000 & 29.8 \\
\hline 2001 & 31.08 \\
\hline 2002 & 35.39 \\
\hline 2003 & 35.76 \\
\hline 2004 & 36.21 \\
\hline 2005 & 36.47 \\
\hline 2006 & 36.49 \\
\hline 2007 & 36.86 \\
\hline 2008 & 40.88 \\
\hline 2009 & 40.67 \\
\hline 2010 & 44.42 \\
\hline 2011 & 45.21 \\
\hline 2012 & 51.08 \\
\hline 2013 & 48.03 \\
\hline 2014 & 47.72 \\
\hline 2015 & 50.52 \\
\hline
\end{tabular}

The purpose of this research is to improve maize production in 2025 using dynamic system approach. To achieve these objectives required the steps contained in the sub methodology, result, and discussion so that it can be concluded. The first thing to do is to make a causal loop, the base model, and develop models to improve production by incorporating scenario addition of new planting area, improved irrigation performance and treatment of maize seed with dynamic system simulation approach.

Simulation can be used in the decision-making process because the decision-making process requires historical data and time then before the decision was applied to the test is done. Quoted from Suryani [16] according to the Law and Kelton [19] simulations can also be used as a tool to solve a problem because the simulation is a real picture of persistent problems.

The dynamic system changes based on time, a complex system of feedback from the system provides the latest information about the state of the system which will then produce the decision of these characteristics, so this research uses a dynamic system approach.

\section{MethodOLOGY}

This chapter will explain about step-by-step solving the problems using system dynamic approach and literature review that is used to support this research. 
A. Research Methodology

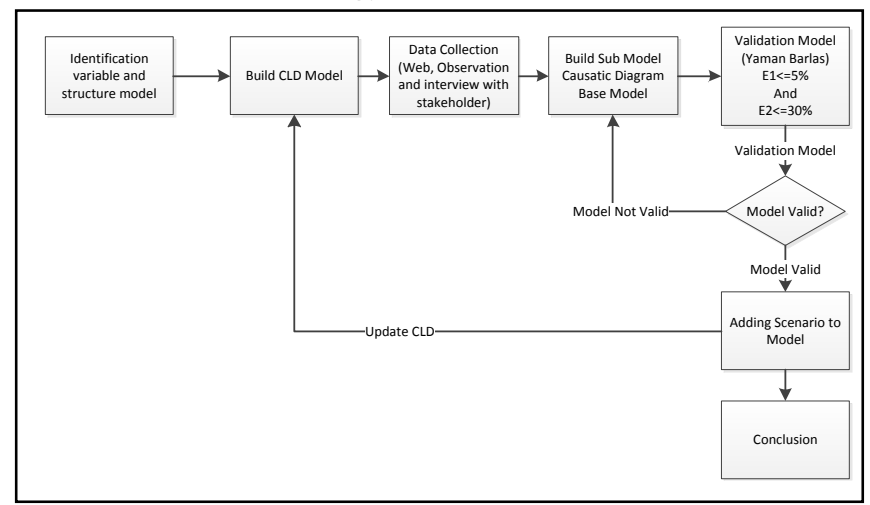

Fig. 1. Research Methodology

Complex dynamical systems approach require formal models and simulation methods to evaluate, improve performance and design new policies [15]. Parameter from stock and flow model designed and adding by knowledge, paper and interview with all stakeholder [10].

Simulation of dynamic systems is a continuous simulation that was developed by Jay Forrester (MIT) in the 1960 s, focuses on the structure and behavior of systems composed between variables and loops feedback (feedback) [16].

Connection and interaction between variables initialization in the causal diagram, the return value (feedback) in the process can be categorized into two parts: Positive Feedback and Negative Feedback.

Five stages in developing a system dynamic models [15]:

\section{Step 1: Problem identification:}

In this stage, we explain and found the main problem, identify key variable and concept, determine the time horizon and characterize the dynamic problem to understanding and designing policy to goals.

\section{Step 2: Dynamic hypothesis:}

Model makers must develop a theory of how to the problem occurs. In this step, need to establish causal loop diagrams that explain the causal relationship between the variables and convert the causal loop diagram into a flow diagram.

\section{Step 3: Define Formulation:}

To determine the dynamic system models, after changing the causal loop diagram into a flow diagram, further, the system must translate into "levels", "rates" and create auxiliary equations. To estimate the number of parameters, behavior relationship, and the initial condition.

\section{Step 4: Testing and check models:}

The purpose of testing is to compare the behavior of simulation models against actual behavior of the system.

\section{Step 5: Policy Formulation and evaluation:}

Modelers could take advantage of the model is valid for designing and evaluating policies for improvement.
Validation models in System Dynamics (SD) simulation models in particular consists of two types of validity test [12]:

(1) Structural validity tests, the function of which is to check whether the structure of the model is an adequate representation of the real structure.

(2) Behavior validity tests, the function of which is to check if the model is capable of producing an acceptable output behavior.

\section{B. System Dynamics}

The system dynamics is an analysis of the real system implemented into a computer simulation model to conceive structure and policy, and understanding changes in system behavior over time[18]. Stocks and Flows Diagram is an essential item in system dynamics approach, Stock diagram describes information process and entity in the system, while, Flows diagram explain the rate of stocks add or subtract from the type of information or entity to the stocks [18].

\section{B.1. Modeling}

According to [3] a model is the abstraction from the real object or system, and the modeling of the system means to catch and abstract system components, relationships, and behavior, by the purpose of the model.

Quoting from Erma Suryani in the book "The modeling and simulation" [12] model is the real idea of the system in the life that became the center of attention and become the core problem. The modeling can be defined as the process of the formation of the model of the system by using a specific formal language.

\section{B.2. Causal Loop Diagram}

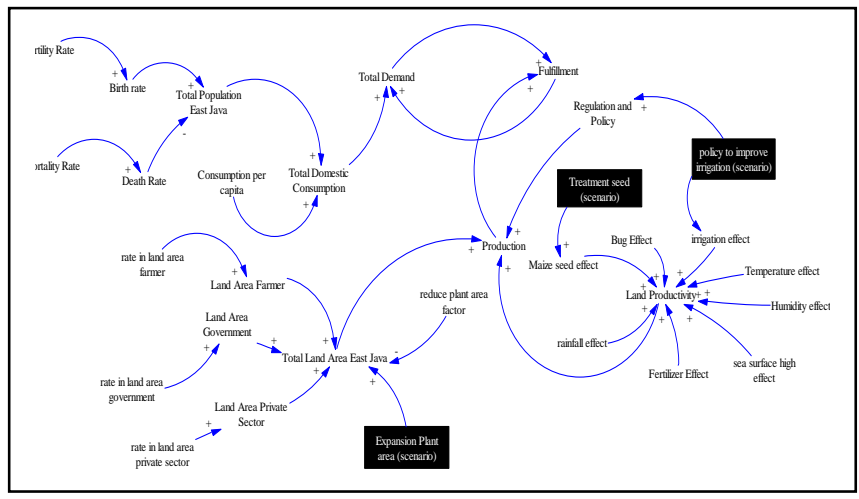

Fig. 2. Causal Loop Diagram of Maize Production.

The causal loop diagram provides an overview of the interaction of each variable in the relation between the behavior of the system and its stakeholders involved[10]. In this research the causal loop diagram describes the population, consumption, land, production, and productivity in East Java, it provides an overview of the interaction between the system, with attention to the number of domestic consumption and can be known to the needs of the production is capable of sufficient in East Java (Fig.2). 
Modeling of dynamic systems generally implements two forms: modeling qualitative, with the eventual goal is to develop a diagram of causation (CLD), which represents the interaction of dynamic factors and stock flow quantitative models with the ultimate goal is to model and simulate dynamic effects of factors are interrelated interact[20].

\section{B.3 Validation Model}

Verification is done by checking against the model and unit model using the facilities at Vensim software. Validation model was tested with mean comparison and varian amplitude (\% error variance) [12].

\section{a. Mean Comparison}

$$
E 1=\frac{|\bar{S}-\bar{A}|}{\bar{A}}
$$

When:

E1 = Mean Comparison

$\bar{S}=$ average of simulation data

$\bar{A}=$ average of real data

Model is valid if $\mathrm{E} 1<=5 \%$

\section{b. \% error variance}

$$
E 2=\frac{|S s-S a|}{S a}
$$

When:

$\mathrm{E} 2=\%$ Error Variance

Ss $=$ Standard deviation of data simulation

$\mathrm{Sa}=$ Standard deviation of real data

Model is valid if E2<=30\%

\section{The model is considered valid when $E 1<=5 \%$ and} E2 $<=30 \%$

\section{RESULTS AND DISCUSSION}

This section shows the diagram flow population, land area, production, and validation model and scenario development with addition new land area.

\section{A. Base Model}

\section{Base Model Harvest and Production Maize}

Figure 3 explains the decreasing and increasing land area impact to maize production and decline or increase maize yield in harvest area has a related to land area, productivity and production in maize commodity.

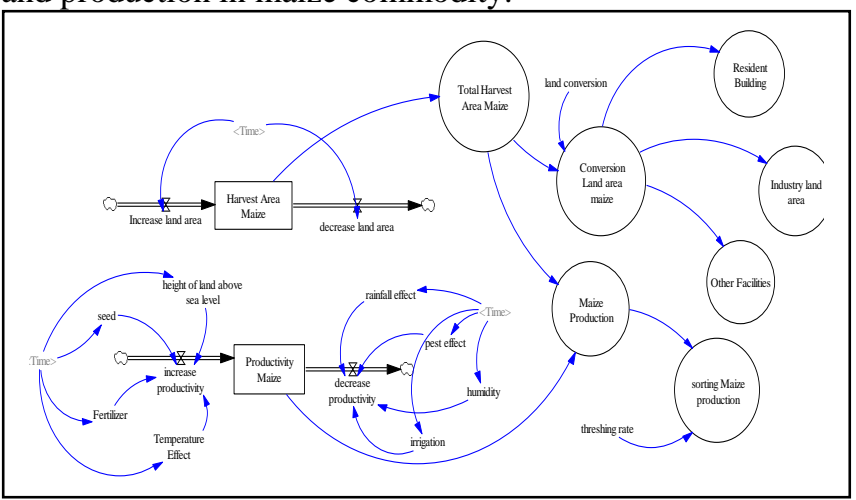

Fig. 3. Base Model harvest and production of maize in East Java.

\section{Base Model Production and Productivity}

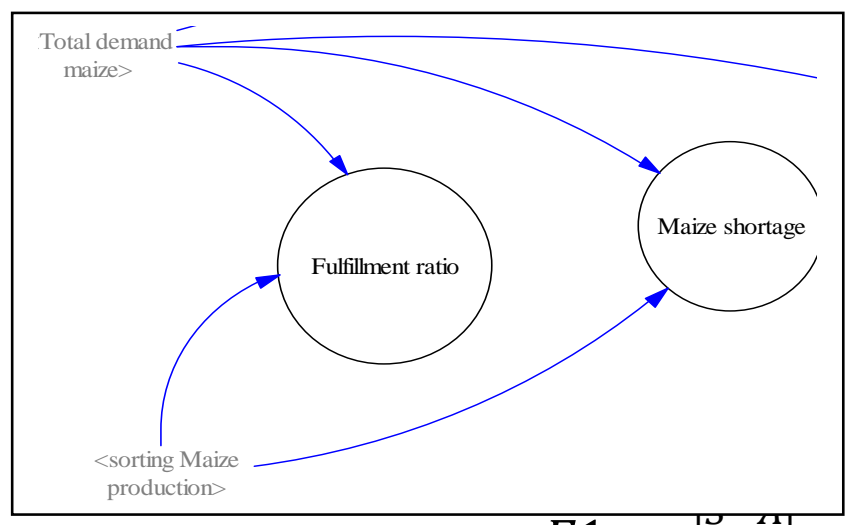

Fig. 4. Base Model Fulfillment ratio maize in Eastfava $\frac{E_{1}}{\bar{A}}$

Fig. 4 describes the fulfillment ratio to find a comparison of the number of communities needs and corn production can be fulfilled.

\section{B. Stock Flow with Scenario}

The scenario in this paper is an expansion of land area, irrigation, and seed treatment. The Ministry of Agriculture will add 500,000 hectares to the expansion of planting area (Perluasan Area Tanam (PAT)), and the second, using seed treatment [18]. Based on the description, the sub-model on the expansion of planting area (PAT) and seed treatment then added in the model for the period 2016 to 2025 (see Fig.5). The results from model development using scenarios of land expansion, irrigation, and seed treatment scenarios are increasing productivity and production of maize.

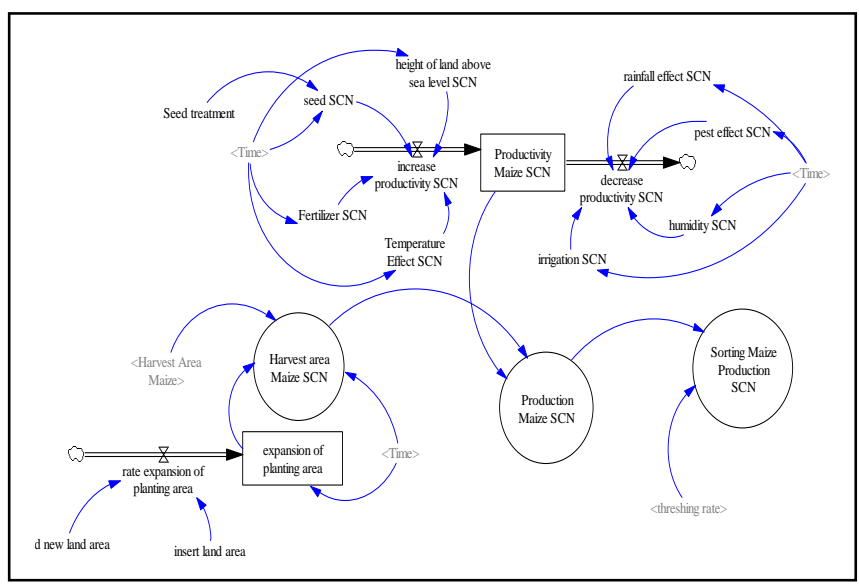

Fig. 5. Model Stock Flow Scenario expansion of planting area, irrigation, and seed treatment.

\section{CONCLUSION}

Based on the results of data processing and analysis and discussions included can be concluded:

a. Regarding developing a model using a dynamic system approach requires understanding and in-depth information on the conditions that exist today, so the model was built to describe the current state. 
b. In this study, the variables that affect the outcome of production are land, land additions/expansion of planting areas, productivity. Production variables affect the amount of consumption of fulfillment, when they are met, then the Province of East Java could do a policy of self-sufficiency by 2016.

c. Scenario for sub modeling expansion plant area variable does not affect in production yield while land conversion not reduced, but the variables of improved irrigation performance and seed treatment have little influence in maize production.

Suggestions for further research are more deriving variables related to productivity such as using geographic information system, human resources, as well as variables related to the production and consumption.

\section{REFERENCES}

[1] The Minister of Agriculture's decree Republic of Indonesia, The Minister of Agriculture's decree about production improvement in maize, paddy and soybean number 549/Kpts/OT.050/8/2018.

[2] F.J. Li, S.C. Dong, and F. Li, "A system dynamics model for analyzing the eco-agriculture system with policy recommendations," Ecol. Model., vol. 227, pp. 34-45, 2012.

[3] D.O. Ferraro, D.E. Rivero, and C.M. Ghersa, "An analysis of the factors that influence sugarcane yield in Northern Argentina using classification and regression trees," Field Crops. Res., vol. 112, pp.149-57, 2009.

[4] R.N. Ellis, K.E. Basford, M. Cooper, J.K. Leslie, and D.E. Byth, "A methodology for analysis of sugarcane productivity trends 1 . Analysis across districts," J. Agric., vol. 52, pp. 1001-1009, 2001.

[5] J.S. Russell, M.K. Wegener, T.R. Valentine, "Effect of weather variables on C.C.S. at Tully simulated by the AUSCANE model," Proc. Aust. Soc. Sugar Cane Technol., vol. 13, pp. 157-163, 1991.

[6] R.A. Lawes, R.J. Lawn, M.K. Wegener, and K.E. Basford, "The evaluation of the spatial and temporal stability of sugarcane farm performance based on yield and commercial cane sugar," Aust. J. Agric. Res., vol. 55, pp. 335-344, 2004.

[7] Institution of central statistics republic of Indonesia, Productivity, land area and production in maize commodity, 2017. [Online]

[8] The Minister of Agriculture Republic of Indonesia, Data Center and Information system of agriculturer (outlook maize), Jakarta: The Minister of Agriculture, 2016.

[9] Z. Mantau, "Competitiveness of Indonesian's Corn in Facing ASEAN Economic Community Era," J. of Agric. Res. and Dev. (J. Litbang Pert.), vol. 35, No. 2, pp. 89-97, June 2016.

[10] A. Chapman, and S. Darby, "Evaluating sustainable adaptation strategies for vulnerable mega-deltas using system dynamics modelling: Rice agriculture in the Mekong Delta's An Giang Province," Vietnam. Sci. of The Total Environ., vol. 559, pp. 326338, 2016.

[11] C. Andersson, L. Karlsson, J. Nedstam, M. Höst, and I.B. Nilsson, "Understanding software processes through system dynamics simulation: A case study," IEEE Proc. Eng. Comp-Based Syst., pp. 41-48, 2002.

[12] Y. Barlas, "Multiple tests for validation of system dynamics type of simulation models," Eur. J. of Oper. Res., vol. 42, pp 59-87, 1989.

[13] J.W. Forrester, System Dynamics: the Foundation Under Systems Thinking, System Dynamic D-402, p.4902, 2010.

[14] L. Regulation, The Provincial Spatial Plan. East Java: Local Regulation in East Java, 2012.

[15] J.D. Sterman, Business Dynamics Systems Thinking and Modeling for a Complex World, 1st ed, McGraw-Hill Companie, Inc, 2000.
[16] E. Suryani, Modelling and Simulation, 1st ed, Yogyakarta: Graha Ilmu, 2005.

[17] Kompas.online, Adequate Animal Feed Allocation, Corn Production Exceeds National Needs, [Online], Available: https://ekonomi.kompas.com/read/2018/08/01/102014926/alokasipakan-ternak-cukup-produksi-jagung-lampaui-kebutuhan-nasional [Accessed 10 Agustus 2018].

[18] A. B. Putra, S. Mukaromah, and N.C. Wibowo. "Analysis of Soybean Production to Achieve Soybean Self-Sufficiency Using System Dynamics Approach,” Proc. IJCST 2017, Vol. 1 No. 1, pp. 413-419, 2017.

[19] K.W. David, Simulation with Arena second edition. McGraw-Hill Companie, Inc, 1998.

[20] J.P. Walters, D.W. Archer, G.F. Sassenrath, J.R. Hendrickson, J.D. Hanson, J.M. Halloran, P. Vadas, J. Vladimir, J. Alarcon," Exploring agricultural production systems and their fundamental components with system dynamics modeling," Ecological Modelling, vol. 333, pp. 51-65, 2016. 